\title{
ANALISIS MOTIVASI DAN PENDAPATAN PADA USAHA PEMELIHARAAN TERNAK BABI SKALA RUMAH TANGGA DI KOTA KUPANG
}

\author{
Defrys R.Tulle', F.Trisakti Haryadi', dan Arinto ${ }^{2}$
}

\section{INTISARI}

Penelitian ini dilaksanakan di Kecamatan Oebobo dan Maulafa, Kota Kupang, dari bulan Juli hingga September 2004. Materi penelitian sebanyak 60 peternak diambil secara purposive random sampling. Tujuan penelitian ini adalah: (1) mengetahui tingkat motivasi peternak dalam memelihara ternak babi, (2) menganalisis faktor-faktor karakteristik internal peternak dan situasional usaha yang mempengaruhi motivasi dalam memelihara ternak babi, (3) menghitung besarnya pendapatan usaha pemeliharaan ternak babi dan kontribusinya terhadap pendapatan rumah tangga, dan (4) mengetahui hubungan antara motivasi dengan pendapatan peternak. Variabel yang diukur meliputi: motivasi beternak, karakteristik internal peternak, karakteristik situasional usaha, biaya, dan penerimaan usaha. Analisis yang digunakan meliputi: analisis deskriptif kuantitatif, binomial logit, dan korelasi Rank Spearman. Hasil penelitian menunjukkan bahwa: 1) sebagian besar peternak di Kota Kupang memiliki motif ekonomi, sosial, dan hiburan yang tinggi serta memiliki tingkat motivasi tinggi dalam beternak babi; 2) motivasi beternak secara nyata dipengaruhi oleh variabel umur $(\mathrm{P}<0,10)$, pengalaman beternak $(P<0,05)$, penghasilan non usaha ternak babi $(P<0,10)$, dan kepemilikan lahan $(\mathrm{P}<0,05) ; 3)$ rata-rata pendapatan dari usaha pemeliharaan ternak babi skala rumah tangga di Kota Kupang adalah sebesar Rp. 3.841.101,22,- per unit ternak per tahun; 4) rata-rata kontribusi pendapatan usaha ternak babi terhadap total pendapatan rumah tangga sebesar $26,69 \%$ dan tergolong jenis usaha sambilan; dan 5) tidak terdapat hubungan yang berarti antara variabel-variabel motivasi beternak dengan pendapatan peternak.

(Kata kunci : Motivasi, Pendapatan, Pemeliharaan ternak babi).

Buletin Peternakan $29(2): 88-96,2005$

\footnotetext{
'Politeknik Pertanian Negeri Kupang, Kupang.

${ }^{2}$ Fakultas Peternakan Universitas Gadjah Mada, Yogakarta.
} 


\title{
MOTIVATION AND INCOME ANALYSIS OF SMALL SCALE PIG FARMING IN KUPANG CITY
}

\begin{abstract}
ABSTARCT
This study was conducted in Sub districts of Oebobo and Maulafa, Kupang City. It was carried out in July to September 2004. Sixty farmers were taken as respondents by purposive random sampling. The objectives of this study were: to know the category of motivation of pig farming; to analyze internal and business situational characteristics influencing motivation of the farmers; to calculate the income from pig farming as well as its contribution on family income, and to study the relationship between motivation and income. Variables measured consisted of motivation; internal characteristics of farmer; business situational characteristics; input and output of pig farming. Data were analyzed descriptively using logit regression model and correlation of Rank Spearman. The results of this study indicated that most of the farmers had high categories of motivation in social, economic and hobby. The category of motivation in pig farming was high. The motivation category in pig farming was significantly affected by age $(\mathrm{P}<0.10)$, experience in pig farming $(\mathrm{P}<0.05)$, non pig farming income $(P<0.10)$ and land ownership $(P<0.05)$. The average income of small scale pig farming in Kupang was Rp.3,841,101.22,-/AU/year. The average contribution of small scale pig farming to total family income was $26.69 \%$. There was no significant relationship between motivation and income of pig farming.
\end{abstract}

(Key words : Motivation, Income, Pig farming).

\section{Pendahuluan}

Secara nasional terlihat bahwa kegiatan usaha peternakan babi ada yang telah dilakukan secara komersil (industri peternakan), namun sebagian besar masih merupakan peternakan rakyat. Selain sebagai cabang usaha utama, usaha peternakan babi dapat dijadikan sebagai usaha sampingan ataupun komplementer bagi masyarakat. Aritonang (1998) menyatakan bahwa, pada usaha peternakan babi rakyat, dipelihara beberapa ekor hingga puluhan ekor. Peternakan babi rakyat menyebar di pedesaan hingga sekitar kota bahkan di dalam kota.

Dari segi ekonomis, ternak babi merupakan salah satu sumber daging dan pemenuhan gizi yang sangat efisien di antara ternak-ternak yang lain, karena: (1) babi memiliki konversi ransum cukup tinggi; (2) babi termasuk prolifik, mampu beranak enam - 12 ekor dan induk dapat beranak dua kali dalam setahun; (3) persentase karkas babi cukup tinggi, mencapai $6580 \%$, sedangkan persentase karkas sapi hanya $50-60 \%$, domba dan kambing $45-55 \%$ serta kerbau $38 \%$; (4) daging babi kandungan lemaknya lebih tinggi sehingga nilai energinyapun tinggi dengan kadar air lebih rendah; (5) penghasil pupuk; dan (6) adaptif terhadap sistim pemakaian peralatan otomatis sehingga menghemat biaya dan tenaga kerja (Aritonang, 1998).

Pemeliharaan ternak babi oleh sebagian masyarakat Kota Kupang adalah kegiatan usaha peternakan yang merupakan bentuk kegiatan komplementer dalam rumah tangga. Berdasarkan data laporan Dinas Pertanian dan Kehutanan Kota Kupang (2003), untuk tiga tahun terakhir, jumlah populasi ternak babi di Kota Kupang mengalami peningkatan. Pada tahun 2000 tercatat 10.580 ekor, tahun 2001 tercatat 15.381 ekor, dan pada tahun 2002 mengalami peningkatan menjadi 20.423 ekor.

Pengembangan ternak babi dipengaruhi oleh aspek sosial budaya, ekonomi, dan faktor teknis (breeding, feeding, dan management). Usaha ternak babi juga memiliki berbagai komponen yang saling berhubungan satu sama lain yakni 1) proses biologis ternak, 2) peternak, 3) kegiatan usaha, dan 4) kegiatan usaha sebagai bisnis. Dari komponen-komponen di atas, 
peternak (manusia) menempati posisi sentral karena sebagai penentu corak dari sistim usaha.

Salah satu aspek penentu keberhasilan pengembangan usaha temak babi dari komponen manusia (peternak) adalah aspek motivasi usaha. Motivasi yang bekerja dalam diri individu berbeda-beda. Ada motif yang begitu kuat sehingga menguasai motif-motif lainnya. Motif paling kuat adalah motif yang menjadi penyebab utama tingkah laku individu pada saat tertentu. Teori Mc Clelland (Gibson et al., 1997) menjelaskan bahwa perilaku manusia didorong oleh tiga jenis kebutuhan, yakni: afiliasi, kekuasaan (power), dan kebutuhan mencapai tujuan. Kekuatan motivasi seseorang dipengaruhi oleh berbagai faktor baik itu faktor internal maupun eksternal (luar) dirinya.

Rendahnya motivasi usaha peternak akan berdampak pada kegiatan usaha. Kondisi ini dapat dilihat dari berbagai bentuk perilaku seperti ketidakseriusan dalam kegiatan usaha, kurang terarahnya kegiatan usaha yang berpengaruh terhadap produktivitas usaha, kurang tanggap dan kurang menguasai ilmu pengetahuan dan teknologi, rendahnya kreativitas, dan usaha yang dilakukan secara ekonomis tidak menguntungkan.

Penelitian ini bertujuan untuk mengetahui tingkat motivasi peternak dalam memelihara ternak babi, menganalisis faktorfaktor karakteristik internal peternak dan situasional usaha yang mempengaruhi tingkat motivasi peternak dalam memelihara ternak babi, menghitung besarnya pendapatan dari usaha pemeliharaan ternak babi dan kontribusinya terhadap pendapatan rumah tangga, dan mengetahui hubungan antara motivasi dengan pendapatan peternak.

\section{Materi dan Metode}

Penelitian ini dilaksanakan di Kecamatan Oebobo dan Maulafa, Kota Kupang, Propinsi Nusa Tenggara Timur, dari Juli hingga September 2004. Kedua kecamatan ini diambil secara random dari empat kecamatan di Kota Kupang. Sebagai responden adalah peternak babi sebanyak 60 peternak yang diambil dengan teknik purposive random sampling. Kriteria responden adalah memiliki kandang di sekitar rumah (kediaman) mereka, telah memelihara ternak babi lebih dari satu tahun, dan pada saat penelitian masih memelihara ternak babi. Teknik pengumpulan data meliputi: observasi, wawancara dengan panduan kuesioner, dan pencatatan. Data yang dikumpulkan meliputi: 1) karakteristik internal peternak yaitu umur, lama mengkuti pendidikan formal, dan pengalaman beternak; 2) karakteristik situasional usaha yaitu curahan waktu kerja, jumlah tanggungan keluarga, penghasilan luar usaha ternak babi, kepemilikan ternak, penggunaan sumber informasi, dan ketersediaan lahan; 3 ) motivasi peternak; dan 4) biaya-biaya yang dikeluarkan dan penerimaan dari usaha pemeliharaan ternak babi.

Motivasi diukur berdasarkan motif yang mendasari peternak dalam memelihara ternak babi meliputi motif sosial, ekonomi, dan hiburan. Pengukuran menggunakan tes dengan pernyataan yang dikembangkan dari motif-motif di atas. Masing-masing jawaban diberi skor (lima strata), mengacu pada skala Likert. Sebelum digunakan, daftar pernyataan diuji validitasnya dengan metode Korelasi Product Moment Pearson dan uji reliabilitas dengan korelasi Spearman Brown estimasi teknik belah dua (Ancok, dalam Singarimbun dan Effendy, 1995).

Hasil uji validitas diperoleh 25 butir pernyataan yang valid dengan koefisien realiabilitas sebesar 0,805 . Lima belas pernyataan merupakan pernyataan untuk mengukur kategori motif ekonomi, delapan pernyataan untuk kategori motif sosial dan dua pernyataan untuk mengukur motif hiburan. Penggolongan kategori masing-masing motif ke dalam dua kategori yakni kategori tinggi dan rendah berdasarkan kisaran skor minimum dan maksimumjawaban.

Data penelitian dianalisis dengan beberapa metode. Analisis deskriptif dilakukan untuk menggambarkan karakteristik dan kategori dari variabel-variabel motivasi peternak.

Analisis pengaruh dari faktor karakteristik internal peternak dan situasional usaha terhadap kategori motivasi menggunakan regresi Binomial Logit (Gujarati, 1995). 
Persamaan regresi Binomial Logit yang digunakan dalam penelitian ini adalah:

$$
\mathrm{Li}=\ln \left(\frac{\mathrm{Pi}}{1-\mathrm{Pi}}\right)=\mathrm{a}_{0}+\mathrm{a}_{1} \mathrm{X}_{1}+\ldots+\mathrm{a}_{9} \mathrm{X}_{9}+\mathrm{e}
$$

$\mathrm{Pi}=$ Peluang peternak dengan tingkat motivasi tinggi;

$a_{0}=$ intersep;

$\mathrm{a} 1, \mathrm{a} 2, \mathrm{a} 3, \ldots, \mathrm{a} 5=$ koefisien regresi;

$\mathrm{X}_{1}=$ umur peternak (tahun);

$\mathrm{X}_{2}=$ lama pendidikan (tahun);

$\mathrm{X}_{3}=$ pengalaman beternak (tahun);

$\mathrm{X}_{4}=$ curahan waktu kerja(jam/unit ternak/hari);

$X_{\mathrm{S}}=$ jumlah tanggungan keluarga (orang);

$\mathrm{X}_{6}=$ penghasilan non usaha ternak babi (Rp/bulan);

$\mathrm{X}_{7}=$ kepemilikan ternak (unit ternak);

$\mathrm{X}_{8}=$ banyaknya sumber informasi yang digunakan (jumlahmedia informasi);

$\mathrm{X}_{9}=$ kepemilikan lahan $\left(\mathrm{m}^{2}\right)$; dan $\mathrm{e}=$ error rumus:

Perhitungan pendapatan menggunakan

$\mathrm{Pd}=$ TR TC(Soekartawi dkk., 1985).

$\mathrm{Pd}=$ Pendapatan peternak dihitung dalam periode 1 tahun ( $\mathrm{Rp} / \mathrm{unit}$ ternak/tahun);

$\mathrm{TR}=$ Total Revenue atau penerimaan $(\mathrm{Rp} / \mathrm{unit}$ ternak/tahun); dan

$\mathrm{TC}=$ Total Cost atau total biaya (Rp/unit ternak/tahun).

Kontribusi pendapatan usaha ternak babi terhadap pendapatan total rumah tangga dihitung dengan rumus:

$\mathrm{Zi}=\frac{\mathrm{Xi}}{\mathrm{Y}} \times 100 \%$ (Soekartawi, 1995).

$\mathrm{Z}=$ kontribusi pendapatan dari usaha ternak babi terhadap keseluruhan pendapatan rumah tangga (\%);

$\mathrm{Xi}=$ pendapatan usaha ternak babi (Rp/unit ternak/tahun); dan

$\mathrm{Y}=$ pendapatan total rumah tangga $(\mathrm{Rp} / \mathrm{tahun})$.
Analisis hubungan antara variabel motivasi dengan pendapatan menggunakan analisis koefisien Korelasi Rank Spearman $\left(\mathrm{r}_{2}\right)$. Persamaan matematis koefisien Korelasi Rank Spearman adalah:

$$
\begin{array}{ll}
\mathrm{r}_{s} & =\text { koefisien Korelasi Rank Spearman; } \\
\mathrm{d}_{\mathrm{i}} & =\text { perbedaan antara dua ranking; dan } \\
N & =\text { jumlah sampel. }
\end{array}
$$

\section{Hasil dan Pembahasan}

\section{Deskripsi karakteristik internal dan situasional usaha}

Karakteristik yang dapat digolongkan sebagai faktor pendukung (kekuatan) dalam usaha pemeliharaan ternak babi adalah umur peternak yang tergolong produktif, lama mengikuti pendidikan formal yang memadai, pengalaman peternak yang cukup lama dalam beternak babi, curahan waktu kerja yang belum efektif, dan jumlah tanggungan keluarga sebagai sumber tenaga kerja (Tabel 1). Faktor- faktor yang menjadi kelemahan adalah rendahnya kepemilikan ternak, penggu-naan sumber informasi yang kurang, serta kepemilikan lahan yang terbatas (Tabel 1).

\section{Motivasi peternak}

Persentase distribusi kategori motif ekonomi, sosial, dan hiburan disajikan pada Tabel 2. Untuk motif ekonomi, sebanyak $80 \%$ masyarakat memiliki kategori tinggi dan $20 \%$ memiliki kategori rendah.Tingginya motif ekonomi dalam memelihara ternak babi karena sikap masyarakat yang mengetahui bahwa dengan suksesnya beternak babi akan meningkatkan kemakmuran keluarga. Selain itu, masyarakat memelihara temak babi sebagai tabungan keluarga karena dapat dijual sewaktuwaktu apabila ada kebutuhan tak terduga. Hal ini menunjukkan bahwa pemeliharaan ternak babi memiliki prospek dijadikan sebagai alternatif kegiatan ekonomi rumah tangga. 
Tabel 1. Nilai rata-rata variabel karakteristik internal dan situasional peternak (Average of farmer's internal and situational characteristics)

\begin{tabular}{lc}
\multicolumn{1}{c}{ Karakteristik (Characteristics) } & Rata-rata (Average) \\
\hline $\begin{array}{l}\text { Umur (tahun) (Age (year)) } \\
\text { Lama pendidikan (tahun) (Length of formal education } \\
\text { (year)) }\end{array}$ & 43,62 \\
$\begin{array}{l}\text { Pengalaman beternak (tahun) } \\
\text { (Experience in pig farming (year)) }\end{array}$ & 10,48 \\
$\begin{array}{l}\text { Curahan waktu kerja (jam/UT/hari) } \\
\text { (Time work allocation (hour/UT/day)) }\end{array}$ & 5,91 \\
$\begin{array}{l}\text { Jumlah tanggung keluarga (orang) } \\
\text { (Number of family member's responsibility (persons)) }\end{array}$ & 2,83 \\
$\begin{array}{l}\text { Penghasilan non usaha ternak babi (Rupiah/bulan) } \\
\text { (Non pig farming income (Rp/months)) } \\
\text { Kepemilikan ternak babi (unit ternak) } \\
\text { (Pig ownership (AU)) }\end{array}$ & 5,00 \\
$\begin{array}{l}\text { Penggunaan sumber informasi (jumlah media) } \\
\text { (Using of information sources (media number)) } \\
\text { Kepemilikan lahan (m2) (Land ownership (m }{ }^{2} \text { ) }\end{array}$ & $780.833,33$ \\
\hline
\end{tabular}

Tabel 2. Nilai persentase distribusi kategori motivasi beternak (Distribution of motivation category)

\begin{tabular}{lcc}
\hline \hline \multicolumn{1}{c}{$\begin{array}{c}\text { Variabel motivasi } \\
\text { (Variabel of motivation) }\end{array}$} & $\begin{array}{c}\text { Kategori rendah (\%) } \\
\text { (Low category) }\end{array}$ & $\begin{array}{c}\text { Kategori tinggi (\%) } \\
\text { (High category) }\end{array}$ \\
\hline Motif ekonomi (Economics motive) & 20,00 & 80,00 \\
Motif sosial (Social motive) & 41,67 & 58,33 \\
Motif hiburan (Hobby motive) & 28,33 & 71,67 \\
\hline Motivasi (Motivation) & 30,00 & 70,00 \\
\hline
\end{tabular}

Motif sosial dan hiburan juga tergolong tinggi. Sebanyak $71,67 \%$ peternak memiliki kategori motif hiburan tinggi mengindikasikan bahwa memelihara ternak babi bukan merupakan kegiatan sulit melainkan kegiatan yang menyenangkan. Untuk motif sosial, kategori tinggi $(58,33 \%)$ tidak berbeda jauh dengan kategori rendah $(41,67 \%)$. Sebagai wilayah perkotaan, cara pandang masyarakat akan status sosial telah bergeser dan berbeda dengan cara pandang masyarakat pedesaan yang berbasis sektor pertanian. Bagi masyarakat pedesaan status sosial dapat ditentukan oleh luasnya lahan pertanian atau banyaknya ternak yang dimiliki.

Peternak dengan kategori motivasi tinggi sebanyak $70,00 \%$ dan motivasi rendah sebanyak $30,00 \%$. Keadaan ini merupakan kekuatan dalam pengembangan usaha pemeliharaan ternak babi sebagai kegiatan ekonomi produktif. Handoko (1997) menyatakan bahwa makin kuat motivasi seseorang, makin kuat pula usahanya untuk mencapai tujuan. 
Tabel 3. Hasil analisis regresi binomial logit pengaruh variabel-variabel bebas terhadap tingkat motivasi (Binomial logit regression analysis on the effect of independent variabels to motivation category)

\begin{tabular}{|c|c|c|c|}
\hline Variabel (Variables) & $\beta$ & $\begin{array}{l}\text { Signifikansi } \\
\text { (Significance) }\end{array}$ & $E(\beta)$ \\
\hline $\begin{array}{l}\text { Umur (tahun) (Age (year)) }\left(\mathrm{X}_{\mathrm{i}}\right) \\
\text { Lama pendidikan (tahun) }\end{array}$ & 0,134 & $0,066^{*}$ & 1,134 \\
\hline $\begin{array}{l}\text { (Length of formal education (year)) }\left(\mathrm{X}_{2}\right) \\
\text { Pengalaman beternak (tahun) }\end{array}$ & $-0,059$ & 0,786 & 0,942 \\
\hline $\begin{array}{l}\text { (Experience in pig farming (year)) }\left(\mathrm{X}_{3}\right) \\
\text { Curahan waktu kerja (jam/UT/hari) }\end{array}$ & 0,929 & $0,041^{*}$ & 2,532 \\
\hline $\begin{array}{l}\text { (Time work allocation (hour/UT/day)) }\left(\mathrm{X}_{4}\right) \\
\text { Jumlah tanggungan keluarga }\end{array}$ & $-0,218$ & 0,605 & 0,804 \\
\hline $\begin{array}{l}\text { (Number of family member's responsibility) }\left(\mathrm{X}_{5}\right) \\
\text { Penghasilan non usaha ternak babi (Rupiah/bulan) }\end{array}$ & 0,024 & 0,941 & 1,025 \\
\hline $\begin{array}{l}\text { (Non pig farming income (Rp/months)) }\left(\mathrm{X}_{6}\right) \\
\text { Kepemilikan ternak babi (unit ternak) }\end{array}$ & 0,001 & $0,064^{*}$ & 1,000 \\
\hline $\begin{array}{l}\text { (Pig ownership) }(A U)\left(\mathrm{X}_{7}\right) \\
\text { Penggunaan sumber informasi (jumlah media) }\end{array}$ & $-0,409$ & 0,412 & 0,664 \\
\hline $\begin{array}{l}\text { Using of information sources(media number)) }\left(\mathrm{X}_{8}\right) \\
\text { Kepemilikan lahan }(\mathrm{m} 2)\end{array}$ & 0,019 & 0,977 & 1.020 \\
\hline \multirow{2}{*}{$\begin{array}{l}\left.\text { (Land ownership) }\left(m^{2}\right)\right)\left(\mathrm{X}_{9}\right) \\
\text { Konstanta }\end{array}$} & $-0,028$ & $0,033^{* *}$ & 0,972 \\
\hline & $-3,467$ & 0,478 & 0,031 \\
\hline Faktor koreksi kebenaran (Percent correct prediction) & & $83,3 \%$ & \\
\hline Chi-square model & & $0,002^{* * *}$ & \\
\hline 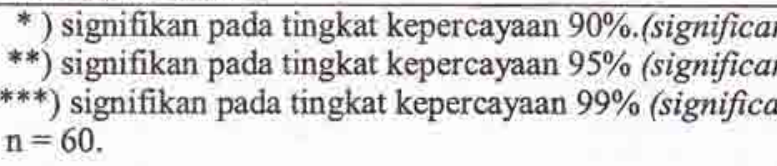 & $\begin{array}{l}\text { the l } \\
\text { the l } \\
\text { the }\end{array}$ & $\begin{array}{l}\text { of } 90 \%) \\
\text { of } 95 \%) \\
\text { of } 99 \% \text {. }\end{array}$ & \\
\hline
\end{tabular}

Faktor-faktor yang mempengaruhi tingkat motivasi

Hasil analisis regresi binomial logit faktor-faktor yang diduga berpengaruh terhadap motivasi memelihara ternak babi disajikan pada Tabel 3. Hasil analisis menunjukkan bahwa pengujian model regresi binomial logit penganuh variabel-variabel karakteristik internal dan situasional terhadap tingkat motivasi secara statistik dapat dipercaya, dengan faktor koreksi kebenaran sebesar $83,3 \%$. Berdasarkan probabilitas chi-square, terlihat bahwa variabelvariabel bebas secara bersama-sama berpengaruh nyata $(\mathrm{P}<0,01)$ pada motivasi beternak. Secara parsial, variabel yang signifikan berpengaruh terhadap motivasi adalah umur $(\mathrm{P}<0,10)$, pengalaman beternak $(\mathrm{P}<0,05)$, penghasilan non usaha ternak babi $(\mathrm{P}<0,10)$, dan kepemilikan lahan $(\mathrm{P}<0,05)$.

Pengaruh nyata dari faktor pengalaman beternak disebabkan oleh tingkat kedewasaan teknis dalam arti keterampilan dalam melaksanakan tugas. Faktor umur mempunyai kaitan dengan kedewasaan psikologis seseorang. Penelitian para ahli menunjukkan bahwa usia mempunyai kaitan pula dengan kedewasaan psikologis (Siagian, 2004). Artinya, semakin lanjut usia seseorang, yang bersangkutan diharapkan semakin mampu menunjukkan kematangan jiwa, semakin bijaksana, semakin 
mampu berpikir secara rasional, semakin toleran terhadap pandangan dan perilaku yang berbeda dari pandangan dan perilaku sendiri, serta semakin mampu mengendalikan emosi dan sifat-sifat lain yang menunjukkan kematangan intelektual dan psikologisnya.

Pendapatan non usaha ternak babi berpengaruh nyata $(\mathrm{P}<0,10)$ terhadap kategori motivasi memelihara ternak babi. Meningkatnya pendapatan cenderung meningkatkan peluang peternak memiliki motivasi tinggi yang disebabkan karena adanya tambahan modal yang dapat digunakan dalam usaha ternaknya. Variabel ini berpengaruh nyata namun sulit didefinisikan karena koefisien yang sangat kecil $(0,001)$ dengan nilai expexted $\beta=1,000$, artinya peningkatan pendapatan non usaha ternak babi memberikan probabilitas yang sama kepada peternak yang memiliki kategori motivasi tinggi maupun rendah.

Kepemilikan lahan berpengaruh nyata $(\mathrm{P}<0,05)$ dengan koefisien negatif dan nilai expexted $\beta<1(0,972)$. Hal ini mengindikasikan bahwa semakin luas lahan yang dimiliki, peternak cenderung memiliki kategori motivasi rendah dibanding kategori motivasi tinggi. Hal ini disebabkan karena dengan kepemilikan lahan yang terbatas akan mendorong peternak untuk memanfaatkan lahan tersebut secara optimal atau lebih efisien dalam memanfaatkannya. Harwood (1979) menyatakan bahwa apabila sumberdaya produksi terbatas, usahatani kecil akan lebih efisien dibandingkan dengan usahatani luas, dengan memadukan usaha ternak dengan budidaya tanaman.

\section{Pendapatan peternak}

Rata-rata dan distribusi biaya per unit ternak per tahun disajikan pada Tabel 4. Dari semua komponen biaya, biaya pakan menempati proporsi terbesar dengan rata-rata Rp. $1.374 .937,31$ per unit ternak per tahun $(61,66 \%)$. Hasil penjumlahan rata-rata total biaya produksi usaha pemeliharaan ternak babi adalah Rp. 2.229.843,90 per unit ternak per tahun.

Rata-rata ternak yang dijual dalam satu tahun sebanyak 1,12 unit ternak, dengan rata-rata penerimaan sebesar Rp. $5.975 .663,28$ per unit ternak per tahun. Rata-rata pendapatan usaha ternak babi per unit ternak per tahun sebesar Rp. 3.841.101,22. Distribusi pendapatan petemak disajikan pada Tabel 5

Persentase terbesar adalah peternak dengan kisaran pendapatan antara $\mathrm{Rp}$ $2.000 .000,00$ Rp $5.000 .000,00(41,67 \%)$. Pendapatan di atas Rp $5.000 .000,00$ per tahun $(26,66 \%)$; pendapatan di bawah $R p$. $1.000 .000,00$ per tahun $(16,67 \%)$, dan pendapatan antara Rp. $1,000,000,00 \mathrm{Rp}$. 2.000.000,00 pertahun sebesar $15,00 \%$.

Distribusi pendapatan di atas, menunjukkan bahwa usaha pemeliharaan ternak babi di Kota Kupang belum memberikan pendapatan yang tinggi. Hal ini, selain karena skala usaha yang relatif kecil, juga karena penerapan prinsip-prinsip ekonomi beternak babi yang belum dilakukan dengan baik oleh peternak.

\section{Kontribusi pendapatan usaha pe-meliharaan} ternak babi terhadap total pendapatan rumah tangga

Hasil perhitungan kontribusi pendapatan usaha ternak babi terhadap total pendapatan rumah tangga per tahun sebesar $26,69 \%$. Menurut Soehadji (1994), tipologi usaha dapat digolongkan berdasarkan skala usaha dan pendapatan peternak. Berdasarkan pendapatan peternak, tipologi usaha peternakan diklasifikasikan ke dalam empat kelompok yakni: 1) usaha sambilan dengan pendapatan dari ternak kurang dari $30 \% ; 2$ ) cabang usaha dengan pendapatan dari budidaya ternak sebesar 30 $70 \%$; 3) usaha pokok dengan pendapatan dari ternak $70 \quad 100 \%$; dan 4) peternakan sebagai usaha industri, mengusahakan komoditas ternak secara khusus (special farming) dengan tingkat pendapatan $100 \%$ dari usaha peternakan. Berdasarkan kriteria ini, maka usaha pemeliharaan ternak babi di Kota Kupang tergolong usaha sambilan hingga cabang usaha dan belum ada yang dijadikan sebagai usaha pokok. Lebih jelasnya, distribusi tipologi usaha dari pemeliharaan ternak babi di Kota Kupang disajikan pada Tabel 6. 
Tabel 4. Rata-rata dan distribusi komponen biaya produksi per unit temak per tahun (Average of component input cost distribution per animal uit/per year)

\begin{tabular}{ccc}
\hline \hline Komponen biaya (Component cost) & $R p$ & $\begin{array}{c}\text { Persentase } \\
\text { (Percentage) }\end{array}$ \\
\hline Biaya tetap (Fixed cost) & $111.183,36$ & 4,99 \\
Penyusutan kandang (Housing depreciation) & $77.053,75$ & 3,46 \\
Penyusutan peraiatan (Equipment depreciation) & $632.653,17$ & 28,37 \\
Biaya Variabel (Variable cost) & $1.374 .973,31$ & 61,66 \\
Bibit (Sow) & $6.515,83$ & 0,29 \\
Pakan (Feed) & $19.594,84$ & 0,88 \\
Obat-obatan plus jasa (Medicine and service) & 7.869 .63 & 0,35 \\
Sewa pejantan (Rent of boar) & $2.229 .843,90$ & 100,00 \\
Biaya lain (Others) & & \\
\hline \multicolumn{2}{c}{ Total }
\end{tabular}

Tabel 5. Distribusi pendapatan usaha pemeliharaan ternak babi (Pig farming income distribution)

\begin{tabular}{|c|c|c|}
\hline Pendapatan (Income) (Rp) & $\begin{array}{c}\text { Jumlah (Total) } \\
\text { (Orang) (Person) }\end{array}$ & $\begin{array}{l}\text { Persentase } \\
\text { (Percentage) }\end{array}$ \\
\hline$\leq 1.000 .000,00$ & 10 & 16,67 \\
\hline$>1.000 .000,00-2,000.000,00$ & 9 & 15,00 \\
\hline$>2.000 .000,00-5.000 .000,00$ & 25 & 41,67 \\
\hline$>5.000 .000,00$ & 16 & 26,66 \\
\hline Total & 60 & 100,00 \\
\hline
\end{tabular}

\section{Hubungan antara motivasi dengan pendapatan}

Hasil analisis korelasi rank Spearman antara variabel-variabel motivasi dengan pendapatan peternak diperoleh koefisien korelasi ( $\mathrm{r}$ ) masing-masing untuk motif ekonomi $(0,162)$, motif sosial $(0,259)$, motif hiburan $(0,062)$ dan motivasi $(0,077)$. Hubungan ini tidak berarti secara statistik karena menunjukkan hubungan yang tidak signifikan.

Walaupun peternak memiliki kategori motif ekonomi dan motivasi yang tinggi, namun tidak memiliki hubungan yang berarti dengan pendapatan. Hal ini disebabkan karena skala usaha yang relatif kecil dan usaha pemeliharaan ternak yang dilakukan oleh peternak belum merupakan bentuk kegiatan ekonomi yang mengutamakan efisiensi usaha. Faktor kendala lain yang dirasakan oleh peternak adalah kesulitan dalam memperoleh pakan karena harganya relatif mahal sehingga berdampak pada kebutuhan modal yang besar dalam beternak.

\section{Kesimpulan}

Berdasarkan hasil penelitian maka dapat disimpulkan bahwa sebagian besar peternak babi di Kota Kupang dilandasi oleh motif ekonomi, sosial, dan hiburan yang tinggi serta memiliki tingkat motivasi beternak tinggi. Faktor-faktor yang berpengaruh terhadap kategori motivasi peternak memelihara ternak babi adalah umur, pengalaman beternak, pendapatan non usaha ternak babi, dan kepemilikan lahan. Rata-rata 
Tabel 6. Distribusi peternak berdasarkan tipologi usaha

(Farmer distribution base on bussiness types)

\begin{tabular}{ccc}
\hline \hline Tipologi usaha (Business type) & $\begin{array}{c}\text { Jumlah (Total) } \\
\text { (Orang) (Person) }\end{array}$ & $\begin{array}{c}\text { Persentase } \\
\text { (Percentage) }\end{array}$ \\
\hline $\begin{array}{c}\text { Sebagai usaha sambilan (Side of business) } \\
\text { Sebagai cabang usaha(Branch of business) }\end{array}$ & 33 & 55 \\
& 27 & 45 \\
\hline Total & 60 & 100,00 \\
\hline
\end{tabular}

pendapatan dari usaha pemeliharaan ternak babi skala rumah tangga di Kota Kupang adalah Rp. $3.841 .101,22$ per unit temak per tahun. Rata-rata kontribusi pendapatan dari usaha ternak babi terhadap total pendapatan rumah tangga sebesar $26,69 \%$ dan tergolong jenis usaha sambilan. Tidak terdapat hubungan yang berarti antara variabel-variabel motivasi beternak dengan pendapatan peternak.

\section{Daftar Pustaka}

Aritonang, D. 1998. Produktivitas Babi Impor di Indonesia. Seminar Ekspor Ternak Potong, Jakarta.

Dinas Pertanian dan Kehutanan Kotamadya Kupang. 2003. Laporan Tahunan 2002, Kupang.

Gibson, J. L., J. M. Ivancevic, and J. H. Donelly. 1997. Organization, Behaviour, Structure, Processes. IRWIN, Chicago.

Gujarati, D, N. 1995. Basic Econometrics. $3^{\text {th }}$ edition. Mc Grow Hill, Singapura.

Handoko, M. 1997. Motivasi: Daya Penggerak Tingkah Laku. Kanisisus, Yogyakarta.
Harwood, R. R. 1979. Small Farm Development, Understanding and Improving Farming System in The Humid Tropics. West View Press. Colorado. USA.

Siagian, S. P. 2004. Teori Motivasi dan Aplikasinya. PT. Rineka Cipta, Jakarta.

Siegel, S. 1994. Statistik Non Parametrik Untuk Ilmu-Ilmu Sosial. PT. Gramedia Pustaka Utama, Jakarta.

Singarimbun, M dan S. Effendy, 1995. Metode Penelitian Survei. LP3ES, Jakarta.

Soehadji. 1994. Paradigma Pembangunan Peternakan Tangguh. Pidato Pengukuhan Gelar Kehormatan Akademik " Doktor Honoris Causa" Universitas Padjajaran, Bandung.

Soekartawi., A. Soeharjo., J. L. Dillon, dan J. B. Hardacker. 1985. Ilmu Usaha Tani dan Penelitian Untuk Pengembangan Petani Kecil. Fakultas Ekonomi Universitas Indonesia, Jakarta.

Soekartawi. 1995. Analisis Usaha Tani. UI Press, Jakarta. 